September - 2020

\title{
Profiles of Online Students and the Impact of Their University Experience \\ Albert Sánchez-Gelabert ${ }^{1}$, Riccardo Valente ${ }^{2}$, and Josep M Duart ${ }^{3}$ \\ 1 Universitat Autònoma de Barcelona (UAB), ${ }^{2}$ Rovira i Virgili University (URV), ${ }^{3}$ Universitat Oberta de Catalunya (UOC)
}

\begin{abstract}
In recent decades, there has been a steady growth in the population who enter higher education in both brick-and-mortar and, in particular, online universities. This has led to an increase in heterogeneous student profiles in a relatively short period of time. The purpose of this paper was to explore the student profiles at a university that gives all its courses online, namely the Universitat Oberta de Catalunya (UOC), and analyse students' perceptions of their university experience. With this goal in mind, we constructed a student typology based on their social conditions and backgrounds using multiple correspondence analysis. Subsequently, an analysis of variance (Kruskall-Wallis test) was run to detect whether there were any differences in students' perceptions of the impact of their university experience $(N=1850)$. Although the prevailing profile of students in the online university continues to reflect students with responsibilities outside of the university (e.g., work and/or family), new profiles have been observed, made up of younger students without any work or family responsibilities. In turn, younger students' distinct perceptions of their university experience has been observed, depending on student profiles, with older students having more intrinsic perceptions, focused on learning and the acquisition of theoretical knowledge.
\end{abstract}

Keywords: online education, online university students, student profiles, distance higher education, impact, social conditions 


\section{Introduction}

In the last few decades, a large number of studies have analysed university students' admission, participation, and graduation, taking into account their social conditions. The conclusions showed an increase in student participation in university as a result of the expansion of education, which in turn has increased the heterogeneity of university student profiles (Ariño Villaroya, Hernández Pedreño, Llopis Goig, Tejerina Montañana, \& Navarro Susaeta, 2008; Soler Julve, 2013; Troiano \& Torrents, 2018). Some of the more salient features of this research pointed to a greater frequency in terms of age (older students), social background, educational access routes, previous educational experience, place of residence, students with external responsibilities (work or family), ethnic minorities, and so on. This trend may have been influenced by a series of changes and innovations that have introduced, creating new rules of play in higher education. The reforms enacted with entry into the European Higher Education Area (EHEA), the abolition of admission quotas for students who have completed higher vocational education and training programmes, and increased university fees have had an impact on opportunities for young people and their strategies for adapting to the new university context (Troiano, Torrents, Sánchez-Gelabert, \& Daza, 2017).

With the implementation of the EHEA (also known as the Bologna Process), changes such as an obligation to be physically present at the university or the use of continuous assessment have had detrimental effects on those students who need to combine their studying with other activities, whether work- or family-related (Elias, Masjuan, \& Sánchez-Gelabert, 2012). As a result of these changes, nontraditional students may find themselves forced to leave university or look for more flexible educational options or systems such as an online university. Although university enrolments have shown a clear upwards trend, most of this growth has been in institutions that offer online courses rather than in those that only offer face-to-face teaching (Ashby, Sadera, \& McNary, 2011). Even so, some authors have stressed that admission and participation processes, as well as student profiles, are not the same in brick-and-mortar and online universities; they have concluded it is unlikely that online education is cannibalizing on-site students in significant numbers (Cavanaugh, 2005).

The dynamic pace of change is particularly apparent in distance education, to the point of redefining the profile of distance university students who have traditionally had to combine their studies with other responsibilities outside of university. In line with this outlook, some studies performed in the 1990 s in countries where distance education was more consolidated, such as Canada, have shown that major changes in the type of students choosing this option have taken place in a relatively short period of time (11 years; Wallace, 1996). Specifically, the results showed an increase in participation by younger students who study full-time at the university and live in urban environments. Some of the explanations proposed by Wallace (1996) attribute the increased economic pressure among students with more responsibilities to the recession and university fee hikes.

Given this background, recent changes in the Spanish context may have triggered an increase or shift of certain student profiles towards the so-called distance universities, which in turn has led to a growing internal diversity of students enrolled in these universities. The importance of these changes lies in the fact that they may generate a new conception of higher education, and a new way of understanding the university experience among the different profiles of students who choose to study at distance universities. 
This research pursued a two-fold purpose. First, it sought to explore the profile of distance university students based on their social conditions, factoring in sociodemographic aspects, external responsibilities, prior education, and social background. Our goal was to identify the sociodemographic composition and internal heterogeneity of distance university student profiles. Second, it proposed to explore the impact of the university experience on different aspects of students' personal and professional lives, and to analyse whether the impact varied among different student typologies.

\section{The Traditional Profile of Distance University Students}

By definition, one of the main features of a distance university is the flexibility it offers, in a broad sense (e.g., schedule, geographical location, hours of study), and the fact that it facilitates participation by a specific student profile that has difficulty attending a brick-and-mortar university. In this respect, some studies highlighted the role of the distance university in the case of students who live in rural areas, geographically remote places, or who must travel long distances to get to a brick-and-mortar university (Bocchi, Eastman, \& Swift, 2004; Cavanaugh, 2005; Dutton \& Dutton, 2002). The existence of distance universities may also increase participation by students who have some type of disability, by avoiding possible interaction problems that may arise at brick-and-mortar universities (Moisey, 2004; Richardson, 2009).

However, over all these factors, the possibility of combining studying with other responsibilities outside of the university, such as work or family, has been the central factor in this notion of flexibility offered by the distance university (Bocchi et al., 2004; Dutton et al., 2002; Sikora, 2002). In this respect, empirical findings have shown that the likelihood of participating in distance universities is higher among students who do not depend financially on their family (Sikora, 2002), and students who combine studying with full-time (Cavanaugh \& Jacquemin, 2015; Hillstock \& Havice, 2014) or parttime employment (Wallace, 1996). Students who combine studying with work has had a clear translation in sociodemographic terms, with online students' average age higher than that of students enrolled at brick-and-mortar universities (Johnson, 2015; Ortagus, 2017).

In parallel with the need to work, some studies have pointed to gender as one of the most discriminating features for distinguishing internally between different distance student profiles (Yukselturk \& Top, 2013). Distance students were characterized by a higher proportion of female students among the university population (Latanich, Nonis, Sarath, \& Hudson, 2001; Wojciechowski, 2004). As an explanation for this increased participation by women, some studies have pointed to the preponderance of women in care-related tasks and the possibility of combining these with more flexible education options (Ortagus, 2017), although other studies questioned whether female students enrolled at distance universities aligned with the stereotype of the full-time mother (Johnson, 2015).

The results in the Catalan context were similar in terms of the increased proportion of female students who stayed at university (Grau-Valldosera \& Minguillón, 2014). Specifically, in the case of students who dropped out in the first semester, we have seen that the likelihood of coming back and staying is higher among women and students who had prior experience in the subject studied. Women's greater ability to return to university and stay also contributed to the increased proportion of women in the distance education population. 
Regarding family social background, studies have shown that a large number of students at distance universities are the first in their family to enter university (Stone, O'Shea, May, Delahunty, \& Partington, 2016). These students have exhibited specific features and needs when it comes to meeting and responding to the institution's requirements.

Although these empirical findings have shown similar patterns, some studies suggested that it was difficult to establish conclusive results due to the incomplete, segmented approaches used in analysing the profile of distance students (Stewart, Bachman, \& Johnson, 2010). Accordingly, the authors proposed a multivariate analysis of online and traditional programmes in which they analysed students' motivation to participate on the basis of a set of sociodemographic variables and the interactive effects among these variables. Among other results, the authors showed the complexity of the online university reality and the existence of interactive effects. In the case of age and gender, for example, the authors stated that young males showed differences in their reasons for entry and participation, and were more motivated intrinsically to complete their studies than were women of the same age (Stewart et al., 2010).

However, this prototypal profile is not static and seems to have shown evidence of change in recent decades. This may have made partial approaches even more confusing. Some studies have suggested a change from mainly older, employed students with clear goals and intrinsic motivations towards a more diverse, dynamic, younger profile that responds rapidly to technological changes (Dabbagh, 2007), or to a rejuvenation process among the population entering distance university education (Wojciechowski, 2004).

To find an answer to these recent changes, researchers have explored lifestyles, perceptions of the institution, and personal attributes as identifying elements of online students (Hillstock \& Havice, 2014). Their results have shown greater participation by women and also by students belonging to majority racial groups (i.e., white, Caucasian students). As regards lifestyles, most students indicated that they were working while studying and that this was their main source for financing their studies (Cavanaugh, 2005; Cavanaugh \& Jacquemin, 2015; Sikora, 2002). In addition, most of them said that they had children and, in about half the cases, children under 18 living in the same home. Thus, students' prototypal profile continues to be characterized by specific life factors: students with responsibilities outside of university such as work and family who choose distance education because it offers flexibility and the possibility of combining studies with other activities.

\section{The Impact of Higher Education}

Many studies have shown the multiplicity, interconnection, and diversity of university's impact. Seeking to identify and conceptualize the different types of impact, some authors have identified different dimensions or factors that differentiate between impacts-short- and long-term, monetary and nonmonetary, intentional and non-intentional, individual and societal (Brennan, Durazzi, \& Tanguy, 2013; Brennan et al., 2010, 2013; McMahon, 2009; Woodall, Hiller, \& Resnick, 2014). Some authors have said that it is not correct to attribute the impact solely to the university experience, and that other factors may be involved such as students' own maturing process or the pressure to choose a profession, among many others (Pascarella \& Terenzini, 2005, p. 534).

The impact of university on the economic dimension, namely career development and the likelihood of being employed, has been frequently analysed. The results seem to be clear in this respect and have 
shown that a higher level of income and a greater likelihood of being employed are both impacts of having entered and graduated from university (McMahon, 2009; Organisation for Economic Cooperation and Development, 2019; Pascarella \& Terenzini, 2005). This phenomenon has also been analysed in the case of distance universities. According to the results, graduating from a distance university course has a positive effect on increased salary, although this varies depending on the programme or degree completed (Castaño-Muñoz, Carnoy, \& Duart, 2016).

Regarding the economic dimension, one of the main motivations expressed by university students for going to university is related to future career and financial aspirations, and the possibility of finding a job or improving future work conditions (Dziewanowska, 2017; Machado, Brites, Magalhães, \& Sá, 2011; Soares et al., 2018). However, many rationales have been involved in distinguishing between the impact that their university experience may have had, both in professional and career terms, and in terms of learning and skill acquisition (Arquero, Byrne, Flood, \& Gonzalez, 2009; Balloo, Pauli, \& Worrell, 2017; Byrne \& Flood, 2005).

These results revealed some interesting variations and differences when students' profiles were taken into account, which has led some authors to talk about the differential role played by age in the reasons for studying at university, and the expectations regarding the impact of the university experience (Balloo et al., 2017; Bye, Pushkar, \& Conway, 2007; Rothes, Lemos, \& Gonçalves, 2017). In general, the results have shown that older students tended to express a higher degree of intrinsic motivation than did their younger fellow students. For their part, younger students were more interested in social dimensions such as making friends at university. In turn, differences were observed when other variables were included, such as students' gender. In sum, male adult students had lower autonomous motivation, while female adult students were overrepresented in a high-quality motivation group, with high values of autonomous motivation and low values of controlled motivation (Rothes et al., 2017). Studies that focused specifically on adult learners stated that the most common motivation for reengaging in education was related to extrinsic motivations such as career development and performance in the labour market (Jenkins, 2017).

Beyond the economic or work aspects, other empirical findings have pointed to a great diversity of individual impacts attributable to the university experience associated with (a) academic, cognitive, and psychosocial aspects; (b) attitudes and values; (c) moral aspects; (d) quality of life; and (e) economic and career aspects (Pascarella \& Terenzini, 2005). Likewise, some authors stated that for most students, the university experience was associated with increased self-confidence, independence, communication skills, understanding other people, and maturity (Brennan et al., 2010).

However, as other studies have pointed out, the impacts vary between older and younger students, as the former may have already acquired some of these competencies or skills in other contexts prior to entering university (Brennan et al., 2010). Other authors have said that students' social conditions or responsibilities-work or family responsibilities-may have influenced the impacts of university experience among university students (Brennan et al., 2010; Pascarella \& Terenzini, 2005). This was particularly significant in the case of distance universities, where the dominant profile was that of older students and/or students who combined studying with other responsibilities outside of university.

The increased heterogeneity of the students enrolled in distance universities may have led to greater diversity in students' understanding and conception of university, and the motivations or objectives they expected from their university experience. These changes, both in the students' profiles and in the 
conceptions of and motivations for university education, may have given rise to differential perceptions of the impact of university experience.

\section{Methodology}

\section{Research Goals and Procedures}

Our first goal was to explore students' main characteristics and draw up a distance student typology, taking into account their life circumstances. Thus, we performed a multiple correspondence analysis (MCA) to identify the most significant factors differentiating students. A series of variables were introduced in the analysis to put all the students in a space that allowed us to identify groups of similar students based on their proximity to other students. Table 1 shows the variables that defined this space (i.e., active variables) and their values (i.e., modalities or categories). Having defined the main factors, these were used to carry out a classification analysis to identify different groups of students with similar features. This enabled us to explore the university's internal heterogeneity with respect to students' social conditions and characteristics.

Our second goal was to analyse whether belonging to a particular type of student typology was associated with a differential assessment of the perceived impact of the university experience. We used the Kruskal-Wallis test-a non-parametric equivalent of the analysis of variance (ANOVA)-to determine student typology-specific differences.

\section{Sample}

The data came from a survey of current and former students at the Universitat Oberta de Catalunya (UOC) in order to analyse this distance university's impact on Catalan society and the Catalan economy. The survey was delivered online through the Qualtrics platform (www.qualtrics.com). A link in the invitation e-mail provided participants with access to a consent form for the processing of personal data. Respondents' explicit consent was a condition sine qua non for participation in the survey. A total of 5,732 respondents completed the survey out of a population of over 50,000 eligible students enrolled at UOC at the time of data collection. For the analysis proposed here, we excluded graduates and dropouts. Thus, we narrowed our focus to students who, at the time of performing the survey, were still at the university studying for a university degree $(N=1,850)$. Quota sampling was used to ensure the same proportions of students in relation to gender and age.

\section{Measures}

In order to explore students' life circumstances, we introduced a series of variables that defined the factorial space. Thus, as shown in Table 1, the variables described various student features such as (a) personal characteristics (e.g., sociodemographic, disability); (b) place of residence; (c) responsibilities outside of university (e.g., family situation, children, current work situation, work situation at the time of admission to the university); (d) previous educational level; and (e) social background (i.e., the family's educational and occupational level). 
Table 1

Eleven Active Variables and 38 Categories: Absolute (n) and Relative (in \%) Frequencies

\begin{tabular}{|c|c|c|c|c|c|c|c|c|}
\hline Variable & $\mathrm{n}$ & $\%$ & Variable & $\mathrm{n}$ & $\%$ & Variable & $n$ & $\%$ \\
\hline Gender & & & $\begin{array}{l}\text { Educational level at } \\
\text { admission }\end{array}$ & & & $\begin{array}{l}\text { Family's educational } \\
\text { level }\end{array}$ & & \\
\hline Male & 786 & 42.5 & Below baccalaureate & 166 & 9.2 & Up to primary education & 629 & 38.9 \\
\hline Female & 1064 & 57.5 & Baccalaureate & 347 & 19.2 & Compulsory education & 248 & $15 \cdot 3$ \\
\hline Total & 1850 & 100 & $\begin{array}{l}\text { Higher vocational } \\
\text { education and } \\
\text { training }\end{array}$ & 505 & 28.0 & $\begin{array}{l}\text { Post-compulsory } \\
\text { secondary education }\end{array}$ & 350 & 21.6 \\
\hline Age groups & & & $\begin{array}{l}\text { Uncompleted } \\
\text { university }\end{array}$ & 443 & 24.5 & University studies & 391 & 24.2 \\
\hline Up to 25 & 27 & 1.5 & University & 244 & 13.5 & Total & 1618 & 100 \\
\hline $26-30$ & 207 & 11.2 & Postgraduate & 101 & 5.6 & \multicolumn{3}{|c|}{ Family's occupational level } \\
\hline $31-35$ & 270 & 14.6 & Total & 1806 & 100 & $\begin{array}{l}\text { Highly skilled white } \\
\text { collar }\end{array}$ & 321 & 30.9 \\
\hline $36-40$ & 275 & 14.9 & Job at admission & & & Low-skilled white collar & 395 & 38.1 \\
\hline $41-45$ & 328 & 17.7 & Yes & 1691 & 91.6 & Highly skilled blue collar & 109 & 10.5 \\
\hline $46-50$ & 336 & 18.2 & No & 156 & 8.4 & Low-skilled blue collar & 213 & 20.5 \\
\hline Over 50 & 407 & 22.0 & Total & 1850 & 100 & Total & 1038 & 100 \\
\hline Total & 1850 & 100 & Family situation & & & Present situation & & \\
\hline Disability & & & Single & 690 & 38.2 & Unemployed & 121 & 6.8 \\
\hline Yes & 350 & 19.0 & Married & 1028 & 56.9 & Retired & 47 & 2.6 \\
\hline No & 1490 & 81.0 & $\begin{array}{l}\text { Divorced or } \\
\text { separated }\end{array}$ & 89 & 4.9 & Working & 1612 & 90.6 \\
\hline Total & 1850 & 100 & Total & 1807 & 100 & Total & 1780 & 100 \\
\hline \multicolumn{3}{|c|}{ Place of residence } & Children & & & & & \\
\hline $\begin{array}{l}\text { Catalonia } \\
\text { (Spain) }\end{array}$ & 1448 & 78.3 & Yes & 587 & 31.7 & & & \\
\hline $\begin{array}{l}\text { Rest of } \\
\text { Spain }\end{array}$ & 324 & 17.5 & No & 1263 & 68.3 & & & \\
\hline Abroad & 77 & 4.2 & Total & 1850 & 100 & & & \\
\hline Total & 1850 & 100 & & & & & & \\
\hline
\end{tabular}

\section{Perceptions of the Impact of Higher Education}

In order to analyse students' opinions regarding the impact of university on different aspects of their personal and professional life, the survey included the following question: "Please state which of the following items best describes the impact that studying at the UOC is having." This was followed by a 
drop-down list with eight different items (see Table 2) and respondents were asked to rate each one on a five-point scale ranging on ranging from 1 (no impact) to 5 (a big impact).

Table 2

Respondents' Perceptions of the Impact of Studying at UOC

\begin{tabular}{llll}
\hline Impact & Mean & SD & $n$ \\
\hline Increase my chances of finding a job & 3.39 & 1.237 & 1823 \\
Improve my theoretical knowledge & 4.15 & 0.841 & 1838 \\
Improve the practical knowledge that I use in my job & 3.23 & 1.276 & 1827 \\
Progress in my career & 3.71 & 1.135 & 1828 \\
Acquire new concepts and new knowledge & 4.28 & 0.795 & 1836 \\
Consolidate concepts and broaden previous knowledge & 4.07 & 0.905 & 1837 \\
Improve my personal development (self-assertion, self- & 4.11 & 0.961 & 1840 \\
discipline) & 3.92 & 0.965 & 1838 \\
Gain an interdisciplinary, cross-cutting vision & & & \\
\hline
\end{tabular}

In order to simplify this information and find common dimensions, an exploratory factor analysis was carried out, applying the principal component extraction method with varimax rotation. The KaiserMeyer-Olkin (KMO) sample adequacy statistic was used to estimate the model's significance and relevance $(\mathrm{KMO}=0.851)$. The principal component analysis established a factorial structure that consisted of two components with a total cumulative explained variance of $62.9 \%$.

The rotated component matrix enabled us to identify each item's extraction and contribution to the different components (Table 3 ).

Table 3

Rotated Component Matrix of the Exploratory Factor Analysis

\begin{tabular}{lrr}
\hline \multicolumn{1}{c}{ Impact } & \multicolumn{2}{c}{ Component } \\
& \multicolumn{1}{c}{1} & 2 \\
\hline Acquire new concepts and new knowledge & 0.810 & 0.179 \\
Improve my theoretical knowledge & 0.794 & 0.219 \\
Gain an interdisciplinary, cross-cutting vision & 0.772 & 0.142 \\
Consolidate concepts and broaden previous knowledge & 0.726 & 0.291 \\
Improve my personal development (self-assertion, self- & 0.681 & 0.158 \\
discipline) & & \\
Progress in my career & 0.272 & 0.828 \\
Improve the practical knowledge that I use in my job & 0.213 & 0.759 \\
Increase my chances of finding a job & 0.122 & 0.749 \\
\hline Quality of measures and average variance & 1 & 2 \\
\hline
\end{tabular}




\begin{tabular}{lcc}
\hline Explained variance & $37.6 \%$ & $25.4 \%$ \\
\hline Composite reliability & 0.87 & 0.82 \\
\hline Average variance extracted & 0.57 & 0.61 \\
\hline $\begin{array}{l}\text { Note. } \text { Extraction method: principal component analysis. Rotation method: Varimax with Kaiser } \\
\text { normalization. The rotation has converged in 3 iterations. }\end{array}$ &
\end{tabular}

As we can see, the first component was composed of indicators associated with an intrinsic dimension of the university experience, associated in turn with knowledge acquisition and personal development. The second component contained a more extrinsic dimension related to improvement in work and professional terms, both in relation to knowledge acquisition and improved opportunities. Both components yielded values of composite reliability (CR) and average variance extracted (AVE) above the corresponding cut-offs (CR > 0.7; AVE > 0.5).

\section{Results}

\section{Discriminating Factors in Distance Education Students' Profiles}

The first step after performing the MCA was to select the factors that defined the space formed by students' life circumstances. The factors were defined by the eigenvalue, through which we calculated the inertia or variance; this inertia decreased progressively in each of the factors. Following the instructions given by LeRoux and Rouanet (2010), the modified ratios were calculated using Benzécri's proposal, and this enabled us to identify the importance of each factors and their explained variance. Thus, ACM allows us to explore and visualize the spatial relationships between the variables. The factors can be understood as the axes of the visual representation and are interpreted by assessing the variables' relevant contributions to the factor.The interpretation given here used the first two factors, which account for about $90 \%$ of the total. The first factor accounted for $76.7 \%$ of the total explained variance, the second for about $13 \%$, and the next two accounted for less than $10 \%$ each $(7.5 \%$ and $3.2 \%$, respectively).

Table 4

MCA with Selection of Active Variable

\begin{tabular}{lcccc}
\hline Factor & Eigenvalue & $\begin{array}{c}\text { Corrected } \\
\text { eigenvalue }\end{array}$ & $\begin{array}{c}\text { \% explained } \\
\text { inertia }\end{array}$ & $\begin{array}{c}\text { \% cumulative } \\
\text { inertia }\end{array}$ \\
\hline 1 & 0.2130 & 0.015 & 76.7 & 76.7 \\
2 & 0.1406 & 0.002 & 12.7 & 89.3 \\
3 & 0.1290 & 0.001 & 7.5 & 96.8 \\
4 & 0.1158 & 0.001 & 3.2 & 100.0 \\
\hline
\end{tabular}

When we analysed the variables' contribution to the first factor, we saw that the three variables related to age, having dependent children, and family situation contributed most to explaining the first factor 
(Table 5). Thus, there was a correspondence between this first factor, and family responsibilities and the life cycle. These modalities associated with these three variables contributed more than $73 \%$ to explaining this factor. Since these variables refer to the students' family sphere, the factor was called family responsibilities.

Table 5

Contributions of Variables and Modalities to Factors

\begin{tabular}{|c|c|c|c|c|c|}
\hline \multicolumn{2}{|l|}{ Variable } & \multicolumn{2}{|c|}{ Modality (positive coordinates) } & \multicolumn{2}{|c|}{ Modality (negative coordinates) } \\
\hline Label & Contr. & Label & Contrib. & Label & Contrib. \\
\hline \multicolumn{6}{|c|}{ Factor 1: Family responsibilities } \\
\hline Age & 28.1 & over $50 \mid 46-50$ & $9.7 \quad 3.2$ & $26-30 \mid 31-35$ & 8.85 .4 \\
\hline Children & 23.6 & $\begin{array}{l}\text { Yes } \\
\text { Married | }\end{array}$ & 16.7 & No & 6.9 \\
\hline $\begin{array}{l}\text { Family situation } \\
\text { Family educat. }\end{array}$ & 22.7 & Separated/divorced & $7.5 \quad 2.5$ & Single & 12.8 \\
\hline level & 9.7 & Up to primary education & 4.8 & University education & 3.0 \\
\hline Prior educat. level & 5.5 & Below baccalaureate & 2.8 & & \\
\hline Present situation & 3.8 & Retired & 2.7 & & \\
\hline Family occup. level & 3.4 & & & $\begin{array}{l}\text { Highly skilled white } \\
\text { collar }\end{array}$ & 2.3 \\
\hline \multicolumn{6}{|c|}{ Factor 2: Social and educational background } \\
\hline Family occup. level & 31.4 & $\begin{array}{l}\text { Low-skilled blue collar } \\
\text { Up to primary }\end{array}$ & 10.4 & $\begin{array}{l}\text { Highly skilled white } \\
\text { collar }\end{array}$ & 19.3 \\
\hline Family educ. level & 27.1 & $\begin{array}{l}\text { Compulsory } \\
\text { Higher Voc. Educ. }\end{array}$ & $4.5 \quad 2.7$ & $\begin{array}{l}\text { University education } \\
\text { University | }\end{array}$ & 19.6 \\
\hline Prior educ. level & 20.7 & Training & 11.0 & Postgraduate & $5.0 \quad 2.2$ \\
\hline Age & 9.3 & & & Over 50 & 6.1 \\
\hline Present situation & 5.8 & & & Retired & 5.1 \\
\hline
\end{tabular}

Figure 1 provides a visual illustration of the contraposition among the variables' modalities: the negative values of the first factor (x) correspond to younger students, either single or with other family situations (other than being in a couple and being divorced or separated). 


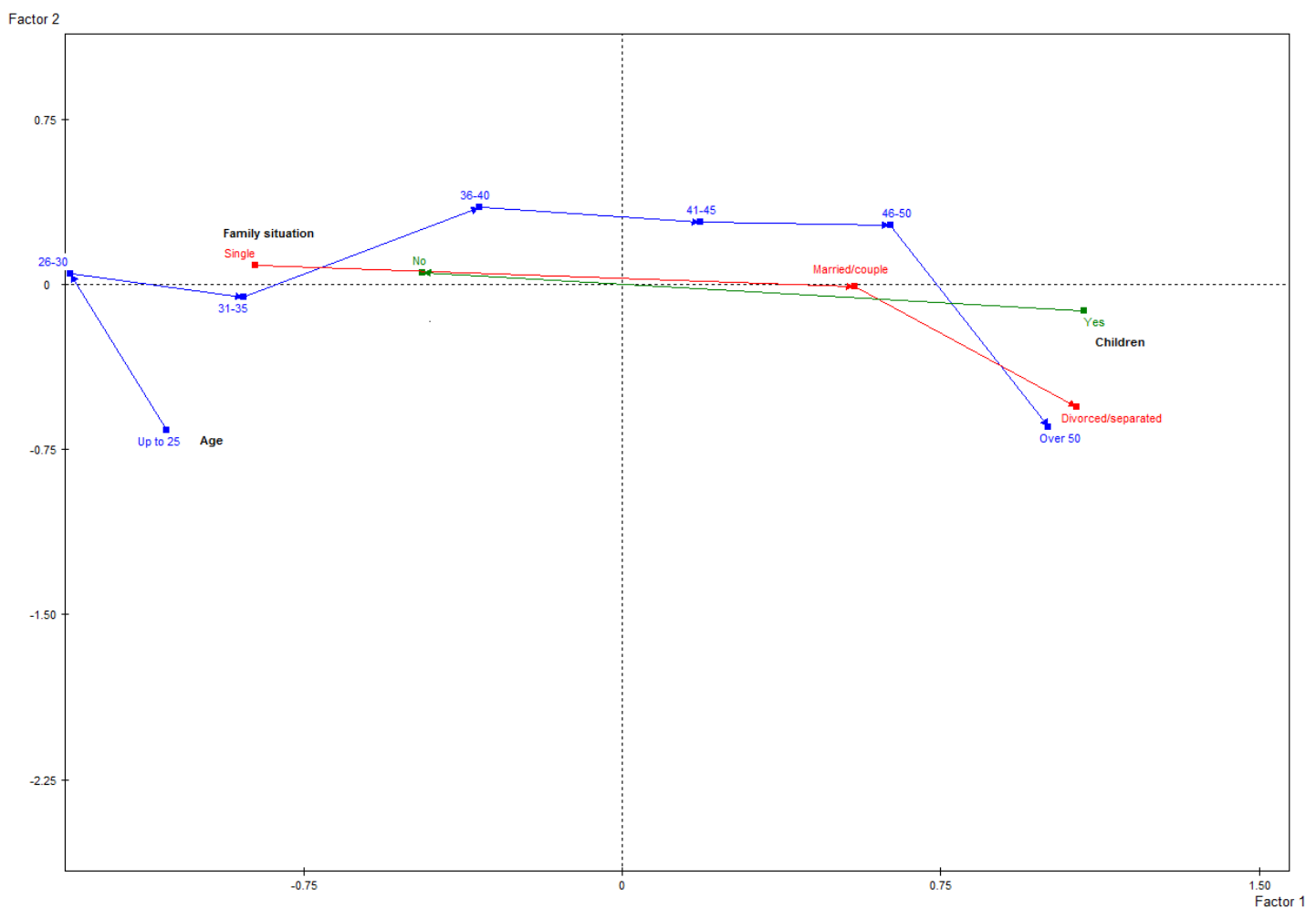

Figure 1. Projection of the variables and modalities that contribute most to factor 1.

As regards the interpretation of the second factor, Table 3 shows that the modalities referring to the students' social background were the most relevant. Both the family educational level and the family occupational level have modalities that contributed more than $50 \%$ of the total to this second factor. Contributing less, but still relevant, the modalities referring to the students' previous educational level contributed about $16 \%$ to the second factor. 


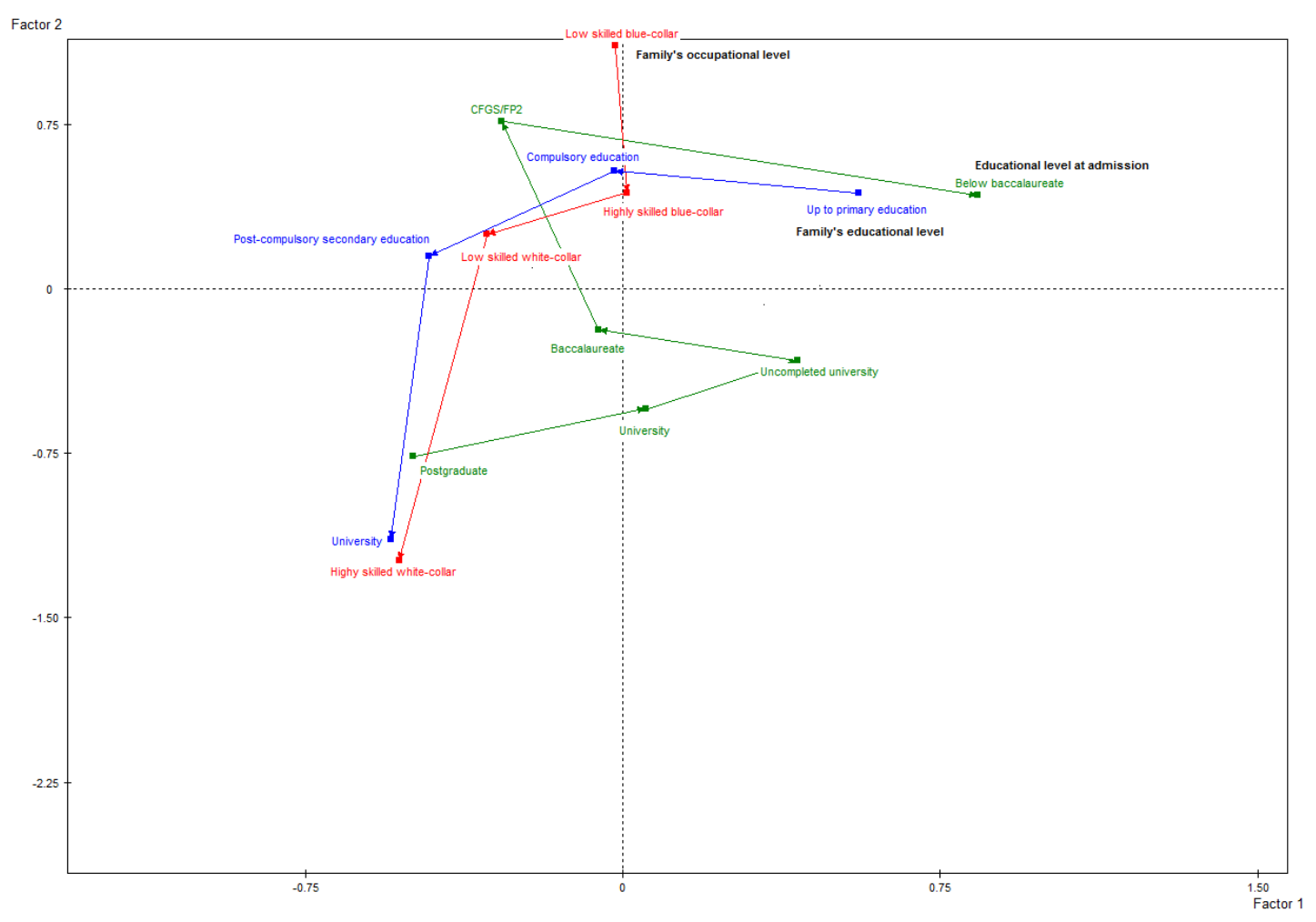

Figure 2. Projection of the variables and modalities that contribute most to factor 2.

Figure 2 shows that the positive coordinates of the second factor (y) included the modalities that refer to families with lower educational (up to post-compulsory studies) and occupational (blue collar and low-skilled white collar) levels. In contrast, the negative coordinates corresponded to the modalities referring to higher family educational and occupational levels (completed university studies and highly skilled occupations).

In addition, there was a relationship between family social background and students' educational level at the time of entry. This showed a contrast between students with lower educational levels (compulsory and higher vocational education and training) in the factor's positive coordinates and students who enter with a baccalaureate or some prior university experience.

\section{A Distance University Student Typology}

From the results of the cluster analysis and taking into account the level of aggregation at each level of the histogram, a typology consisting of five student types was chosen, based on each type's social conditions. Figure 3 shows the scatter of individuals within the space defined by the first two factors described above.

The first group-employed students-represented more than a third of the sample $(n=647)$ and was composed of students aged between 30 and 40, single, without children, and working at the time of entry in university. They entered university through profession-focused forms of admission (i.e., higher vocational education and training) and, to a lesser extent, with a previous university degree. They were related to families with a social background characterized by a high educational level (i.e., university 
studies) and high occupational levels (i.e., highly skilled white collar). This type had a weak association with male students.

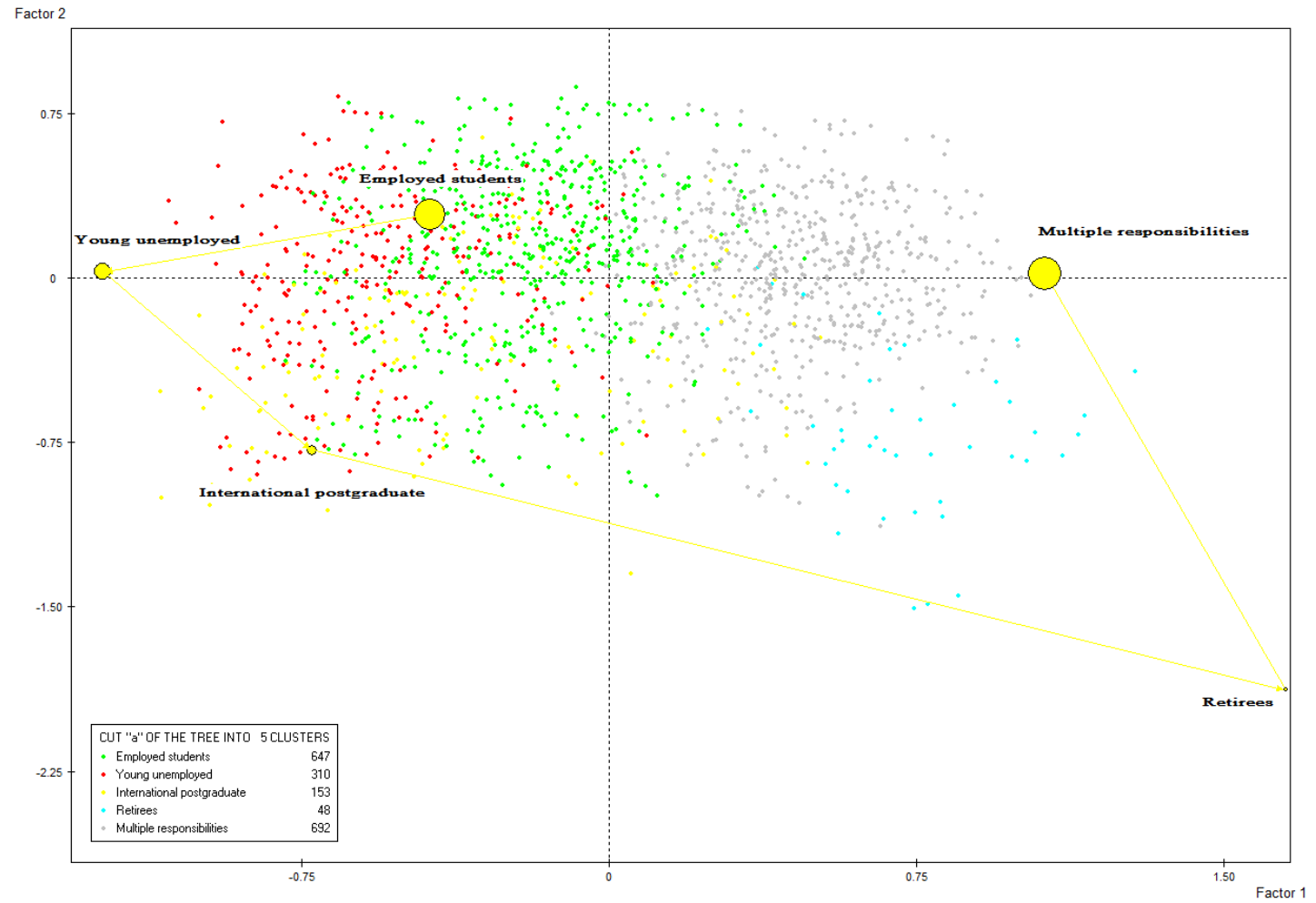

Figure 3. Student typology by social condition.

A second group-young unemployed-corresponded to the group of younger students (i.e., 26-30 years) who were unemployed, and had no work or childcare responsibilities outside university $(n=310$; 16.8\%). They entered university from baccalaureate studies, and their family's social background was characterized by parents with average education and occupation levels (i.e., post-compulsory education, low-skilled white collar). This is the only group that was associated with students with any kind of disability. It showed a slight female bias.

International postgraduate students represented $8.3 \%$ of the sample $(n=153)$ and were characterized by students in postgraduate studies who resided in a foreign country. They come from highly educated families with high occupational levels (i.e., highly skilled white collar and highly skilled blue collar). As in the previous case, this group had a slight female bias.

The group of retired students was the largest minority, with slightly less than 50 students who represented $2.6 \%$ of the total $(n=48)$. These were mainly students over 50 years old, male, and, to a lesser extent, with other university degrees obtained prior to entering the distance university.

Finally, the last group-multiple responsibilities - was the most numerous and represented $37.4 \%$ of the total $(n=692)$. As their name suggests, these students had both work and family (i.e., dependent children) responsibilities. They were associated with low previous educational levels (i.e., below baccalaureate) or with uncompleted university experiences, and low family educational levels as well (i.e., up to primary education). 


\section{The Impact of the University Experience by Student Profile}

Finally, we analysed the impact perceived by different types of students as a result of their university experience. The results of the Kruskal-Wallis test (Table 6) revealed that the differences by student type in their ratings of university impact were statistically significant both in relation to the intrinsic dimension associated with knowledge acquisition $\left(\mathrm{x}^{2}(4)=42.525 ; p<0.000\right)$ and in relation to the extrinsic dimension related with career improvement and acquisition of professional competencies $\left(\mathrm{x}^{2}(4)=34.518 ; p<0.000\right)$.

Table 6

Results of the Kruskal-Wallis Test

\begin{tabular}{|c|c|c|c|c|}
\hline Component & Student typology & $n$ & $\begin{array}{l}\text { Average } \\
\text { range }\end{array}$ & Post-hoc pair-wise comparison \\
\hline \multirow{6}{*}{$\begin{array}{l}\text { Intrinsic } \\
\text { dimension / } \\
\text { knowledge }\end{array}$} & Employed students & 633 & 835.60 & Retirees $^{* *}$; Multiple responsibilities ${ }^{* *}$ \\
\hline & Young unemployed & 305 & 843.88 & Retirees**; ${ }^{* *}$ Multiple responsibilities* \\
\hline & $\begin{array}{l}\text { International } \\
\text { postgraduate students }\end{array}$ & 147 & 841.42 & Retirees ${ }^{* *}$ \\
\hline & Retirees & 42 & 1217.60 & \\
\hline & $\begin{array}{l}\text { Multiple } \\
\text { responsibilities }\end{array}$ & 663 & 968.03 & Retirees* \\
\hline & Total & 1790 & & \\
\hline \multirow{6}{*}{$\begin{array}{l}\text { Extrinsic } \\
\text { dimension / } \\
\text { professional }\end{array}$} & Employed students & 633 & 924.94 & Retirees** \\
\hline & Young unemployed & 305 & 930.94 & Retirees** \\
\hline & $\begin{array}{l}\text { International } \\
\text { postgraduate students }\end{array}$ & 147 & 855.15 & Retirees ${ }^{* *}$ \\
\hline & Retirees & 42 & 458.83 & \\
\hline & $\begin{array}{l}\text { Multiple } \\
\text { responsibilities }\end{array}$ & 663 & 887.70 & Retirees $* *$ \\
\hline & Total & 1790 & & \\
\hline
\end{tabular}

Note. ${ }^{*} \mathrm{p}<0.05 .{ }^{* *} \mathrm{p}<0.001$.

Specifically, the students with multiple responsibilities and, most especially, the retired students showed a greater average range in the intrinsic dimension score associated with the acquisition of theoretical knowledge. There was also an age-related pattern, with older students (i.e., students with multiple responsibilities and retirees) showing significant differences compared with the younger students, whether unemployed or working.

With respect to the dimension associated with professional competencies, it was seen that retired students had a significantly lower score compared to their fellow students. Indeed, the pair-wise comparison found significant differences between the retired students and the other distance student profiles. 


\section{Conclusion and Implications}

The results show the importance of social conditions as a differentiating factor for today's online distance university students. Students can be differentiated by their life cycle and, specifically, by their family situation and external responsibilities, such as having dependent children and work responsibilities. This is in line with the findings of other studies on distance students (Cavanaugh \& Jacquemin, 2015; Dutton et al., 2002; Sikora, 2002). In turn, the introduction of social background enables us to identify a second factor for differentiating and discriminating among students on the basis of their family social background. Students with a higher social background-families with university education who are highly qualified-are differentiated from the rest of the students, revealing a new internal differentiating factor in the case of the distance university. This brings to light a certain degree of diversity in UOC students' social background, although students who are the first in their family to enter university still make up the majority, as other studies have suggested (Stone et al., 2016).

Different student types emerge from these two factors, hinting at a certain degree of internal heterogeneity in the distance students' profile, with a total of five student types. Although differences and features are observed that are specific to each profile, two of the five types (i.e., employed students and multiple responsibilities) account for three out of four students, and become a core student profile in the distance university. However, alongside these two groups, three other student types are observed that contribute further heterogeneity to distance students: retired students, on the one hand, and international postgraduate students and young unemployed, on the other. The last two groups bring to light the existence of a substantial group of students who share similarities with the traditional student profile in brick-and-mortar universities, namely, young students, without any family or work responsibilities, who enter university through academic pathways. This group's relative weight is by no means insignificant, as it accounts for $16.8 \%$ of the total sample. These students may account for the recent rejuvenation of the distance university student profile that has been observed by other international studies as a result of recent social and institutional changes (Dabbagh, 2007; Wallace, 1996; Wojciechowski, 2004). These results may point to the existence of a new relationship between the brick-and-mortar and distance university models, in that the distance university may be attracting a student profile that traditionally studied at the brick-and-mortar university, diverging from the trends suggested by other studies (Cavanaugh, 2005).

The importance of this diversity in the distance university student profile lies in the fact that it leads in turn to a differential perception of university's impact on different aspects of students' personal and professional life. Thus, older students, whether those who have multiple responsibilities or, especially, those who are retired, show a more intrinsic conception of university's impact. For instance, they refer more often to aspects associated with the acquisition and consolidation of new knowledge and with improving their personal development.

On the other hand, with respect to the more extrinsic or professional dimension, retired students give significantly lower scores than the other student types analysed, insofar as the younger students and the employed students perceive that university has a greater impact in professional or extrinsic terms. These results are consistent with studies that showed the role played by age in the reasons for studying at university and the expectations regarding the university experience's impact (Balloo et al., 2017; Bye et al., 2007), and specifically in the trend shown by older students towards a higher degree of intrinsic motivation than their younger fellow students. 
The internal diversity of distance students and the impacts of the university experience indicate a degree of heterogeneity that goes beyond the traditional conception of distance education. In turn, this scenario enables us to delineate or infer multiple rationales for university entry and participation in university, driven by student profiles who traditionally did not consider this education option. For example, second opportunity rationales are observed by which students without any prior higher education and who come from low or intermediate family educational levels are able to acquire a university qualification. These upward social mobility strategies can be observed both among the students with family and work responsibilities (i.e., multiple responsibilities) and among those who are unemployed.

In addition, the decision to study at a distance university may be driven by expressive motivations and the acquisition of knowledge in different subjects at different times in life, such as demonstrated by retirees. This portrays distance education as an institution for lifelong education. These rationales coexist with other more accreditation-focused, career-focused, or specialization-focused rationales, expressed by young students with prior university experience (i.e., international postgraduate students), with work responsibilities (i.e., employed students), or the unemployed (i.e., young unemployed).

Within the framework of this university population rejuvenation process, it would be interesting to delve into the reasons and motivations for studying at a distance university. The economic recession and increased university fees may have had an impact on the educational decisions of the students who opt for distance education as a strategy for reducing the indirect cost of studying. It is also possible that the younger population has acquired new conceptions of university and education. That is a naturalization of the online environment and distance learning which is no longer an obstacle to entering university. These results show that the distance university has become established as a lifelong educational institution, irrespective of the students' age and their social conditions, and it may satisfy a considerable diversity of needs. 


\section{References}

Ariño Villaroya, A., Hernández Pedreño, M., Llopis Goig, R., Tejerina Montañana, B., \& Navarro Susaeta, P. (2008). El oficio de estudiar en la Universidad: compromisos flexibles [The profession of studying at university: flexible commitments]. València: Publicacions de la Universitat de València

Arquero, J. L., Byrne, M., Flood, B., \& Gonzalez, J. M. (2009). Motives, expectations, preparedness and academic performance: A study of students of accounting at a Spanish university. Revista de Contabilidad, 12(2), 279-299. https://doi.org/10.1016/S1138-4891(09)70009-3

Ashby, J., Sadera, W. A., \& McNary, S. C. (2011). Comparing student success between developmental math courses offered online, blended, and face-to-face. Journal of Interactive Online Learning, 1O(3), 128-140.

Balloo, K., Pauli, R., \& Worrell, M. (2017). Undergraduates' personal circumstances, expectations and reasons for attending university. Studies in Higher Education, 42(8), 1373-1384. https://doi.org/10.1080/03075079.2015.1099623

Bocchi, J., Eastman, J. K., \& Swift, C. O. (2004). Retaining the online learner: Profile of students in an online MBA program and implications. Journal of Education for Business, 79(4), 245-253. https://doi.org/10.3200/JOEB.79.4.245-253

Brennan, J., Edmunds, E., Houston, M., Jary, D. W., Lebeau, Y., Osborne, M. J., \& Richardson, J. T. E. (2010). Improving what is learned at university: An exploration of the social and organisational diversity of university education. London, UK: Routledge.

Brennan, J., Durazzi, N., Tanguy, S. (2013). Things we know and don't know about the wider benefits of higher education: A review of the recent literature (BIS Research Paper No. 133, URN BIS/13/1244). London: UK: Department for Business, Innovation and Skills.

Bye, D., Pushkar, D., \& Conway, M. (2007). Motivation, interest, and positive affect in traditional and nontraditional undergraduate students. Adult Education Quarterly, 57(2), 141-158. https://doi.org/10.1177/0741713606294235

Byrne, M., \& Flood, B. (2005). A study of accounting students' motives, expectations and preparedness for higher education. Journal of Further and Higher Education, 29(2), 111-124. https://doi.org/10.1080/03098770500103176

Castaño-Muñoz, J., Carnoy, M., \& Duart, J. M. (2016). Estimating the economic payoff to virtual university education: A case study of the Open University of Catalonia. Higher Education, 72(1), 1-24. https://doi.org/10.1007/s10734-015-9935-1

Cavanaugh, J. K. (2005). Are online courses cannibalizing students from existing courses? Journal of Asynchronous Learning Networks, 9(3), 3-8. https://doi.org/10.24059/olj.v9i3.1781

Cavanaugh, J. K., \& Jacquemin, S. J. (2015). A large sample comparison of grade based student learning outcomes in online vs. face-to-face courses. Journal of Asynchronous Learning Network, 19(2). https://doi.org/10.24059/olj.v19i2.454 
Dabbagh, N. (2007). The online learner: Characteristics and pedagogical implications. Contemporary Issues in Technology and Teacher Education, 7(3), 217-226.

https://doi.org/10.1017/So950268810000580

Dutton, J., Dutton, M., \& Perry, J. (2002). How do online students differ from lecture students? Journal of Asynchronous Learning Networks, 6(1), 1-20.

https://doi.org/10.24059/olj.v6i1.1869

Dziewanowska, K. (2017). Value types in higher education - Students' perspective. Journal of Higher Education Policy and Management, 39(3), 235-246.

https://doi.org/10.1080/1360080X.2017.1299981

Elias, M., Masjuan, J. M., \& Sánchez-Gelabert, A. (2012). Signs of reengagement? In M. Vukasović, P. Maassen, M. Nerland, B. Stensaker, R. Pinheiro, \& A. Vabø (Eds.), Effects of higher education reforms (pp. 21-42). Rotterdam: SensePublishers. https://doi.org/10.1007/978-94-6209-0163

Grau-Valldosera, J., \& Minguillón, J. (2014). Rethinking dropout in online higher education: The case of the Universitat Oberta de Catalunya. International Review of Research in Open and Distributed Learning, 15(1), 290-308. https://doi.org/10.1007/s10734-015-9921-7

Hillstock, L. G., \& Havice, P. A. (2014). Exploring characteristics of retained first-year students enrolled in non-proximal distance learning programs. Journal of College Student Retention, 15(4), 575-603. https://doi.org/10.2190/CS.15.4.f

Jenkins, A. (2017). Adult learning and qualifications in Britain. Journal of Education and Work, 3O(4), 445-455. https://doi.org/10.1080/13639080.2016.1196347

Johnson, G. M. (2015). On-Campus and fully-online university students: Comparing demographics, digital technology use and learning characteristics. Journal of University Teaching \& Learning Practice, 12(1). 1-13.

Latanich, G., Nonis Sarath, A., \& Hudson, G. I. (2001). A profile of today's distance learners: An investigation of demographic and individual difference variables of distance and non-distance learners. Journal of Marketing for Higher Education, 11(3), 1-16.

https://doi.org/10.1300/J050v11no3

LeRoux, B., \& Rouanet, H. (2010). Multiple correspondence analysis. Thousand Oaks, CA: SAGE.

Machado, M. D. L., Brites, R., Magalhães, A., \& Sá, M. J. (2011). Satisfaction with higher education: Critical data for student development. European Journal of Education, 46(3), 415-432. https://doi.org/10.1111/j.1465-3435.2011.01489.x

McMahon, W. W. (2009). Higher learning, greater good. Baltimore: The Johns Hopkins University Press. 
Moisey, S. D. (2004). Students with disabilities in distance education: Characteristics, course enrollment and completion, and support services. Journal of Distance Education, 19(1), 7391.

Organisation for Economic Co-operation and Development. (2019). Education at a glance 2019: OECD indicators. Paris, France: OECD Publishing. https://doi.org/10.1787/f8d7880d-en

Ortagus, J. C. (2017). From the periphery to prominence: An examination of the changing profile of online students in American higher education. The Internet and Higher Education, 32, 47-57. https://doi.org/10.1016/J.IHEDUC.2016.09.002

Pascarella, E. T., \& Terenzini, P. T. (2005). How college affects students: A third decade of research. The Jossey-Bass higher and adult education series (Vol. 2). Indianapolis: Jossey-Bass.

Richardson, J. T. E. (2009). The attainment and experiences of disabled students in distance education. Distance Education, 30(1), 87-102. https://doi.org/10.1080/01587910902845931

Rothes, A., Lemos, M. S., \& Gonçalves, T. (2017). Motivational profiles of adult learners. Adult Education Quarterly, 67(1), 3-29. https://doi.org/10.1177/0741713616669588

Sikora, A. C. (2002). A profile of participation in distance education: 1999-200o. Postsecondary education descriptive analysis reports (Report No. ED469987). Washington, DC: National Center for Education Statistics. Retrieved from https://eric.ed.gov/?id=ED469987

Soares, A. B., Leme, V. B. R., Gomes, G., Penha, A. P., Maia, F. A., Lima, . . Araújo, A. M. (2018). Academic expectations of students in the first years of higher education. Arquivos Brasileiros de Psicologia, 7o(1), 206-223.

Soler Julve, I. (2013). Los estudiantes universitarios. Perfiles y modalidades de vinculación con el estudio en la universidad española. . [University students. Profiles and modalities of engagement with the studies in the Spanish university]. (Doctoral dissertation, University of Valencia, Valencia, Spain). Retrieved from http://roderic.uv.es/handle/10550/30171

Stewart, C., Bachman, C., \& Johnson, R. (2010). Students' characteristics and motivation orientations for online and traditional degree programs. Journal of Online Learning and Teaching, 6(2), 367-379.

Stone, C., O’Shea, S., May, J., Delahunty, J., \& Partington, Z. (2016). Opportunity through online learning: Experiences of first-in-family students in online open-entry higher education. Australian Journal of Adult Learning, 56(2), 146-169.

Troiano, H., \& Torrents, D. (2018). La evolución del acceso a la universidad en Cataluña: ¿Cómo la explicamos? [How can we explain the enrollment trends in Catalan university?] Revista Española de Sociología, 27(1).127-136. https://doi.org/10.22325/fes/res.2018.8

Troiano, H., Torrents, D., Sánchez-Gelabert, A., \& Daza, L. (2017). Evolución del acceso a la universidad y de la elección de titulación universitaria entre la población joven en Catalunya 
[Evolution of university access and degree choice among young people in Catalonia].

Cuadernos de Relaciones Laborales, 35(2), 281-303. https://doi.org/10.5209/CRLA.56775

Wallace, L. (1996). Changes in the demographics and motivations of distance education students. International Journal of E-Learning \& Distance Education, 11(1), 1-31.

Wojciechowski, A. (2004). The relationship between student characteristics and success in an online business course at West Shore Community College (Doctoral dissertation). Available from ProQuest Dissertations and Theses database (UMI No. 3154513).

Woodall, T., Hiller, A., \& Resnick, S. (2014). Making sense of higher education: Students as consumers and the value of the university experience. Studies in Higher Education, 39(1), 48-67. https://doi.org/10.1080/03075079.2011.648373

Yukselturk, E., \& Top, E. (2013). Exploring the link among entry characteristics, participation behaviors and course outcomes of online learners: An examination of learner profile using cluster analysis. British Journal of Educational Technology, 44(5), 716-728.

https://doi.org/10.1111/j.1467-8535.2012.01339.x

\section{Athabasca}

University

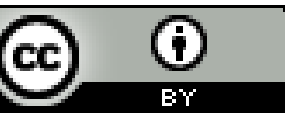

